KAPL-P-000052

(K96062)

$$
\text { CONF-960805- - }
$$

TPV ENERGY CONVERSION A REVIEW OF MATERIAL AND CELL RELATED ISSUES

I.B. Bhat, J.M. Borrego, R.J. Gutmann A.G. Ostrogorsky

August 1996

\begin{abstract}
$\underline{\text { NOTICE }}$
This report was prepared as an account of work sponsored by the United States Government. Neither the United States, nor the United States Department of Energy, nor any of their employees, nor any of their contractors, subcontractors, or their employees, makes any warranty, express or implied, or assumes any legal liability or responsibility for the accuracy, completeness or usefulness of any information, apparatus, product or process disclosed, or represents that its use would not infringe privately owned rights.
\end{abstract}

Operated for the U. S. Department of Energy

by KAPL, Inc. a Lockheed Martin company

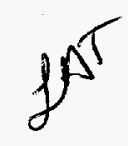




\section{DISCLAIMER}

This report was prepared as an account of work sponsored by an agency of the United States Government. Neither the United States Government nor any agency thereof, nor any of their employees, makes any warranty, express or implied, or assumes any legal liability or responsibility for the accuracy, completeness, or usefulness of any information, apparatus, product, or process disclosed, or represents that its use would not infringe privately owned rights. Reference berein to any specific commercial product, process, or service by trade name, trademark, manufacturer, or otherwise does not necessarily constitute or imply its endorsement, recommendation, or favoring by the United States Government or any agency thereof. The views and opinions of authors expressed herein do not necessarily state or reflect those of the United States Government or any agency thereof. 


\section{DISCLAIMER}

Portions of this document may be illegible in electronic image products. Images are produced from the best available original document. 


\title{
TPV Energy Conversion : A Review of Material and Cell Related Issues
}

\author{
I. B. Bhat, J. M. Borrego, R. J. Gutmann and A. G. Ostrogorsky \\ Center for Integrated Electronics and Electronic Manufacturing \\ Rensselaer Polytechnic Institute \\ Troy, New York 12180-3590
}

\section{Abstract}

This paper presents an overview of thermophotovoltaic (TPV) energy conversion using low band gap semiconductor photovoltaic cells. Physics of PN junctions related to TPV cells is described and the factors that affect overall cell efficiencies are outlined. Current status of bulk and epitaxial growth of TPV materials and cell fabrication issues are also described.

\section{Introduction}

The use of PN junctions for the direct conversion of thermal radiation into electrical power was suggested by Aigrain (1961). The first attempt to achieve thermophotovoltaic (TPV) energy conversion was reported by Wedlock $(1961,1963)$ using Ge PN junctions, with an efficiency of $4.2 \%$ obtained at an input power density of $0.28 \mathrm{Watts} / \mathrm{cm}^{2}$. Recently there has been renewed interest in TPV energy conversion because of advances in two different areas. One advance is the development of high quality low band gap semiconductor alloys used in infrared lasers and detectors, and as the lower band gap cell in tandem solar cells. The second advance is the development of special ceramic radiation emitters which allows control of the spectral characteristics of thermal radiation, thus enabling the use of larger band gap materials like silicon.

Figure 1 is a schematic diagram of a TPV energy conversion system, consisting of a radiant heat source, a selective filter and a TPV cell which is a semiconductor PN junction. The selective filter is used to reflect the radiation that cannot be absorbed by the TPV cell back to the source to increase conversion efficiency. A review of each of the components of the TPV system is outside the scope of this paper. Here, we briefly review energy conversion using TPV cells and the materials and cell technology for TPV systems.

\section{TPV Energy Conversion using PN Junctions}

A semiconductor $\mathrm{PN}$ junction converts radiation energy into electrical energy as illustrated in Fig. 2. If photons with energy larger than the band gap energy $E_{G}$ illuminate the PN junction, the main effect is the generation of hole-electron pairs. If these hole-electron pairs are generated close to the depletion layer of the PN junction, they can diffuse to the edge of the depletion layer where they are collected. The electric field of the depletion layer separates the collected holeelectron pairs causing the electrons to go to the $\mathrm{N}$-region and the holes to the P-region. The separated electrons and holes can produce a voltage across the terminals of the PN junction and an external current if there is an electrical connection across its terminals. This combination of voltage and current provides electrical power to an external load. The maximum photocurrent which the junction can provide to an external load is related to the number of photons with 
energy above $\mathrm{E}_{\mathrm{G}}$ present in the radiation spectrum. If $\mathrm{N}_{\mathrm{PH}}(\varepsilon)$ represents the photon flux density of photon energy, $\varepsilon$; then the maximum photocurrent density, $\left(J_{P H}\right)_{M \wedge x}$, is given by:

$$
\left(J_{P H}\right)_{M A X}=\int_{E_{G}}^{\infty} N_{P H}(\epsilon) d \epsilon
$$

The maximum open circuit voltage that the junction is able to develop is equal to the contact or diffusion potential, $V_{D}$, across the depletion layer. It is usually assumed that the maximum value of this contact potential is equal to $\mathrm{E}_{\mathrm{G}} / \mathrm{q}$. The maximum power output $\mathrm{P}_{\mathrm{MAX}}$, that the $\mathrm{PN}$ junction can provide is given by the product of the maximum photocurrent density, $\left(\mathrm{J}_{\mathrm{PH}}\right)_{\mathrm{MAX}}$, and the open circuit voltage, $\mathrm{E}_{\mathrm{G}} / \mathrm{q}$. It is given by :

$$
P_{M A X}=E_{G} \int_{E_{G}}^{\infty} N_{P H}(\epsilon) d \epsilon
$$

The efficiency, $\eta$, defined as the ratio of the power output density to the total power density of the source radiation spectrum is given by the equation:

$$
\eta=\frac{E_{G} \int_{E_{G}}^{\infty} N_{P H}(\epsilon) d \epsilon}{\int_{0}^{\infty} \epsilon N_{P H}(\epsilon) d \epsilon}
$$

A plot of the above equation assuming the source to be a black body at a temperature $\mathrm{T}_{\mathrm{S}}$, is given by the lower curve (without filter) in Fig. 3. Notice that the maximum efficiency has a value of $44 \%$ and is obtained when $\mathrm{E}_{\mathrm{G}}=2.17 \mathrm{kT}_{\mathrm{S}}$, where $\mathrm{k}$ is the Boltzmann's constant. So, if the source temperature is $2000^{\circ} \mathrm{K}$, then the optimum band gap is $0.37 \mathrm{eV}$. Another possible way to define the efficiency is to use the power density of the radiant source spectrum which the cell can absorb in the denominator of Eq. 3. Then, the expression for the efficiency becomes:

$$
\eta=\frac{E_{G} \int_{E_{G}}^{\infty} N_{P H}(\epsilon) d \epsilon}{\int_{E_{G}}^{\infty} \epsilon N_{P H}(\epsilon) d \epsilon}
$$

The upper curve (Ideal Reflective Filter) of Fig. 3 corresponds to the above equation, with the efficiency increasing as $\mathrm{E}_{\mathrm{G}}$ increases. This indicates that in order to increase the efficiency of the TPV cell, the energy below the band gap that cannot be absorbed by the cell needs to be reflected from the cell and absorbed by the thermal radiator. This can be achieved by using IR spectral filters. However, one cannot increase the efficiency without bound, because the overall power density will decrease if most of the radiation is reflected back to the source.

The efficiencies calculated using Eqs. 3 and 4 are the maximums that can be achieved. A practical cell will have losses which reduce the above values. One of the main losses is related to the fact that the current-voltage characteristics of a PN junction under dark conditions is an exponential law. For the case of a PN junction under illumination the $\mathrm{J}-\mathrm{V}$ characteristics are given by the relation: 


$$
J=-J_{P H}+J_{0}(\exp q V / n k T-1)
$$

Where $\mathrm{J}_{\mathrm{PH}}$ is the cell photocurrent density produced by the photon spectrum of the radiation source. $V$ is the terminal voltage across the cell, $\mathrm{J}_{0}$ is the saturation or dark current of the cell, $\mathrm{n}$ is the diode ideality factor, and $\mathrm{T}$ is the cell temperature. The above equation assumes that there is no series resistance associated with the cell. If the terminal voltage is zero, i.e., cell short circuited, the cell current $\mathrm{J}_{\mathrm{SC}}=-\mathrm{J}_{\mathrm{PH}}$. If the cell is open circuited, then $\mathrm{V}_{\propto}$ is given by:

$$
V_{\alpha .}=\frac{n k T}{q}\left(\ln \frac{J_{P H}}{J_{0}}-1\right)
$$

The maximum power density, $\mathrm{P}_{\mathrm{MAX}}$, that can be obtained from a $\mathrm{PN}$ junction cell having a photocurrent, $\mathrm{J}_{\mathrm{PH}}$, is less than the product of the open circuit voltage times the photocurrent density. Their ratio is called the Fill Factor (FF) of the cell :

$$
F F=\frac{P_{M A X}}{V_{O C} J_{P H}}
$$

Figure 4 is a plot of the Fill Factor as a function of the open circuit voltage and it shows that the Fill Factor decreases as the open circuit voltage, $V_{\alpha}$, decreases. Another factor that reduces the efficiency of the cell is the fact that the $\mathrm{V}_{\propto}$ is less than the band gap voltage, $\mathrm{E}_{\mathrm{G}}$ /q. Their ratio is called the Voltage Factor, $\mathrm{VF}=\mathrm{qV}_{\alpha} / \mathrm{E}_{\mathrm{G}}$. The last factor which reduces the efficiency further is that not all of the hole-electron pairs generated by the absorbed photons are collected by the $\mathrm{PN}$ junction, and do not produce photocurrent. The ratio of the photocurrent, $\mathrm{J}_{\mathrm{PH}}$, to the maximum photcurrent density, $\left(\mathrm{J}_{\mathrm{PH}}\right)_{\mathrm{MAX}}$, i.e., total number of photons with energy larger than the band gap, is called the collection efficiency, $\eta_{\mathrm{C}}$. The practical cell efficiency, $\eta_{\mathrm{CELL}}$, is related to the efficiencies, $\eta$, of Eqs. 3 and 4 by:

$$
\eta_{C E L L}=V F \cdot F F \eta_{C} \eta
$$

The above equation shows that the factors which degrade the efficiency of the cell from what can be expected from Eqs. 3 and 4 are the Voltage Factor, the Fill Factor and the Collection Efficiency. Solar cells made of Silicon and GaAs have Voltage Factors between 0.7 and 0.8 . TPV cells made of lower band gap materials are expected to have still lower Voltage Factors, close to 0.6. Figure 4 shows that the Fill Factor for PN junctions having a low value of open circuit voltage is around 0.6 . The collection efficiency of typical solar cells is above 0.8 , so assuming this lower bound for TPV cells the product of the several factors in Eq. 8 is $0.6 \times 0.6 \times 0.8 \approx$ 0.29 . This means that it is expected that the efficiency of TPV cells would be approximately $1 / 3$ of the value which can be expected from the values given in Fig. 3.

The material parameters which directly affect the values of the Fill Factor, Voltage Factor 
and Collection Efficiency are the optical absorption constant, $\alpha$; the intrinsic carrier concentration, $\mathrm{n}_{i}$, the lifetime, $\tau$, and surface or interface recombination velocity, $s$. The saturation or dark current density, $J_{0}$, depends directly on $\tau$ and $s$. For low band gap $(0.5 \mathrm{eV}$ to $0.6 \mathrm{eV}) \mathrm{PN}$ junctions, $J_{o}$ is in the order of $\mathrm{mA} / \mathrm{cm}^{2}$ because of the large value of the intrinsic concentration. The collection efficiency depends upon $\alpha, \tau$ and $s$. In addition, it is necessary to have the length of the TPV cell longer than the optical absorption depth $(1 / \alpha)$ so that the photons with energy above the band gap are absorbed in the TPV cell and produce hole-electron pairs. The absorption constant of direct low band gap materials is of the order of $10^{3}$ to $10^{4} \mathrm{~cm}^{-1}$ so the TPV cells have to be between 5 to $10 \mu \mathrm{m}$ thick. This should be compared to GaAs and InP solar cells which usually are 1 to $2 \mu \mathrm{m}$ thick.

\section{TPV Materials and Epitaxial Growth}

For specific thermal sources, the semiconductor with the appropriate band gap should be chosen for optimum performance. For example, for a $1100^{\circ} \mathrm{C}$ black body source, a cell with a band gap of $0.5 \mathrm{eV}$ will provide the maximum power. However, for a source with a temperature of $1900^{\circ} \mathrm{C}$, a $0.7 \mathrm{eV}$ cell will be optimum. Hence, ability to tailor the band gap of the cells to meet the specific need should be considered while developing new materials technology. Two material systems are under investigation at present at various laboratories. The first one is the $\operatorname{In}_{\mathrm{x}} \mathrm{Ga}_{1-\mathrm{x}}$ As ternary material system whose band gap can be varied from $1.43 \mathrm{eV}$ to $0.36 \mathrm{eV}$, by varying the $x$ value from 0 to 1 . The second one is a $\mathrm{Ga}_{x} \operatorname{In}_{1-x} S b$ system covering the range from $0.17 \mathrm{eV}$ to $0.73 \mathrm{eV}$. Figure 5 shows the relationship between the band gap and the lattice constant for various III-V and II-VI compound semiconductors. In this section, we will review the status of the growth of these two material systems and their suitability for TPV cell fabrication.

Growth of InGaAs is a mature technology since $\mathrm{In}_{0.53} \mathrm{Ga}_{0.47} \mathrm{As} / \mathrm{InP}$ is used for emitters and detectors in fiber optic communications. $\operatorname{In}_{0.53} \mathrm{Ga}_{0.47} \mathrm{As}$ has a band gap of $0.74 \mathrm{eV}$ and is lattice matched to InP so that high quality epitaxial layers can be grown on readily available InP substrates. Moreover, the better understanding of the processing/etching technology makes InGaAs a very attractive material for TPVs. Unfortunately, for TPV application, a slightly lower band gap, in the 0.5 to $0.6 \mathrm{eV}$ range is optimum so that standard materials currently being grown for lasers and detectors cannot be used. Growth of $\ln _{x} \mathrm{Ga}_{1-x} \mathrm{As}$ on $\mathrm{InP}$ with $\mathrm{x}$ in the range from 0.68 to 0.79 is needed. Epitaxial growth of these materials with reduced band gap is difficult because suitable lattice matched substrates are not available. So the price one has to pay for optimizing the band gap is the increased dislocations due to the lattice mismatch. If grown on InP, various dislocation reduction techniques have to be employed to reduce the dislocation density in the cell active area; so optimizing the band gap is not offset by the high density of dislocations. Several groups have investigated this approach during the last two years and have made substantial improvement in the quality of the lattice mismatched structures.

To illustrate the effect of lattice mismatch on the cell performance, Wojtczuk et al. (1995) used metallorganic vapor phase epitaxy (MOVPE) growth to deposit InGaAs of different composition ( $\mathrm{x}$ from 0.53 to 0.79 ) directly on InP substrates. The compositions were chosen such that the band gap ranged from $0.74 \mathrm{eV}$ to $0.5 \mathrm{eV}, 0.74 \mathrm{eV}$ being the lattice matched case. As the band gap was decreased below about $0.6 \mathrm{eV}$, the TPV cell open circuit voltage decreased precipitously owing to the formation of high density of dislocations in the layer. It is clear from 
this study that a graded buffer layer to relieve the lattice mismatch is required in order to get high quality InGaAs cells of lower band gap. Sharps et al. (1995) used step-graded buffer layers to reduce the effects of lattice mismatch of about $1 \%$. A lattice matched $\operatorname{In}_{0.53} \mathrm{Ga}_{0.47}$ As is first grown on $\mathrm{InP}$ and then the $\mathrm{x}$ value is step-graded from 0.53 to 0.67 over a thickness of several microns using as many as 5-6 layers. Finally, a p-on-n TPV cell structure is grown on this layer. This method has produced TPV cells with improved open circuit voltages compared to the direct growth of InGaAs on InP.

An alternative material we have been exploring is bulk and epitaxially grown GaInSb (Milnes and Polyakov, 1993). GaInSb is preferable to InGaAs because one need not have to use potentially dangerous arsine or phosphine gases to grow the epitaxial layers. Moreover, the GaSb substrates should be less expensive in the long run compared to InP because the growth of bulk $\mathrm{GaSb}$ is carried out at lower temperature and does not require high pressure furnaces. However, there is limited amount of work carried out in this material system compared to that of InGaAs system; hence, significant development in materials and processing has to be carried out before comparable cells can be made.

At Rensselaer Polytechnic Institute (RPI), GaInSb layers were grown using MOVPE technique in a horizontal low pressure reactor (Ehsani et al., 1996). Trimethylindium (TMI), trimethylantimony (TMSb) and trimethylgallium (TMGa) were used as the precursors. Undoped, n- type and p-type layers were grown by introducing proper dopant precursors. P-type layers were grown using $\mathrm{Si}$ (silane as the precursor) and n-type layers were grown using $\mathrm{Te}$ (diethyltellurium as the source). As in the case of InGaAs, no lattice matched substrates are available for GaInSb growth. For a $0.55 \mathrm{eV}$ band gap cell, the $\mathrm{x}$ value in $\mathrm{Ga}_{\mathrm{x}} \mathrm{In}_{1-\mathrm{x}} \mathrm{Sb}$ should be about 0.8 which corresponds to a lattice mismatch of about $1.1 \%$ with GaSb. Hence, it is necessary to introduce step-graded layers to accommodate the lattice mismatch between the epilayer and the substrate.

Figure 6 shows a typical GaInSb p-on-n TPV device structure grown on GaSb substrates. Circular small area $\mathrm{p}$-on- $\mathrm{n}$ devices with radii of 700 microns were fabricated by mesa etching. The I-V curve of a typical GaInSb p-on-n diode is shown in Fig. 7. The device exhibits an ideality factor of 1.2 and a saturation current density of $2 \times 10^{-5} \mathrm{~A} / \mathrm{cm}^{2}$. These results indicate that use of GaInSb for TPV application is promising.

One drawback of the above GalnSb system is the unavailability of lattice matched substrates. This problem can be overcome by growing quaternary compounds such as GaInAsSb. By adding an appropriate amount of $\mathrm{As}$ into $\mathrm{GaInSb}$, one can make the epilayer lattice match the GaSb substrate, and at the same time have independent control of the band gap. However, it is found that the growth of such a quaternary system is extremely difficult because of the widely different vapor pressures of column $\mathrm{V}$ elements, namely $\mathrm{Sb}$ and $\mathrm{As}$. Some success using molecular beam epitaxy (MBE) (Choi et al., 1994) and liquid phase epitaxy (LPE) (Iyer et al., 1993) has been achieved in growing GalnAsSb layers. Another solution for the lattice mismatch problem is the growth of ternary bulk GaInSb wafers. In the next section the approach at Rensselaer to grow bulk GaInSb is outlined. 


\section{Boule Growth of Semiconductors for TPV Applications}

Single crystal boules of the III-V compounds are grown from the melt by slow plane-front solidification. The most successful techniques are: (1) the crystal pulling by the Czochralski and Kyropoulos processes (Hurle, 1994), and (2) directional solidification in crucibles by the Vertical Bridgman (VB) process (Monberg, 1994). Growth of most of the III-V compounds, such as InP or GaAs crystals is involved because of the high vapor pressure of phosphorus or arsenic over the melt. To prevent the evaporation of the volatile elements, the surface of the melt is covered by a layer of $\mathrm{B}_{2} \mathrm{O}_{3}$ (molten glass).

GaSb single crystals can be grown without encapsulation, since the vapor pressure of the melt at $710^{\circ} \mathrm{C}$ is $-3 \times 10^{-6} \mathrm{mmHg}$. The most comprehensive study of Czochralski growth and characterization of GaSb was conducted at ATT Bell Laboratories (Sunder et al., 1986). The $\mathrm{Sb} / \mathrm{Ga}$ ratio in the melt was 1.001 , to compensate for Sb evaporation during synthesis and growth. A high purity hydrogen atmosphere was used to minimize formation of $\mathrm{Ga}_{2} \mathrm{O}_{3}$ scum on the melt surface, which presents a key problem during seeding and promotes twinning and disoriented growth. The undoped crystals exhibited p-type conductivity of $\sim 1$ to $2 \times 10^{16} \mathrm{~cm}^{-3}$, most likely due to vacancies or anti-site defects. Commercial wafers of $\mathrm{GaSb}$ are now readily available.

Bulk single crystals of III-V ternary compounds of interest for TPV $\left(\mathrm{Ga}_{1-x} \mathrm{In}_{\mathrm{x}} \mathrm{Sb}\right.$ and $\mathrm{Ga}_{1-x} \mathrm{In}_{\mathrm{x}} \mathrm{As}$ ) are difficult to grow from the melt using the traditional methods. Melt growth results in inhomogeneous crystals, because of the strong separation between the solidus and liquidus lines in the pseudo-binary phase diagrams, which causes segregation between the components.

Bonner et al. (1990) succeeded in growing $\sim 3 \mathrm{~cm}$ diameter, substrate quality $\mathrm{Ga}_{1-\mathrm{x}} \mathrm{In}_{\mathrm{x}} \mathrm{As}$ single crystals by LEC. About $60 \%$ of $\sim 250 \mathrm{gm}$. melts were solidified into single crystals $(0.02$ $<\mathrm{x}<0.12)$. Strong longitudinal variation in composition was reported. By using melt replenishment in LEC, Kusunoki et al. (1993) grew $\mathrm{Ga}_{1-x} \operatorname{In}_{x} A s$ crystal having uniform composition, $x=0.05$. However, the crystal was quite small (diameter $<1 \mathrm{~cm}$, length $=4.5 \mathrm{~cm}$ ). Garandet et al. (1990) grew $\mathrm{Ga}_{1-x} \mathrm{In}_{\mathrm{x}} \mathrm{Sb}$ single crystals $(0.01<\mathrm{x}<0.1)$ using the VGF process. Longitudinal variation in composition was reported in $1 \mathrm{~cm}$ diameter, $5 \mathrm{~cm}$ long crystals. By using a variation of the Czochralski process (solute-feeding Czochralski), Tanaka et al. (1994) succeeded in pulling homogeneous $1.5 \mathrm{~cm}$ diameter, $2 \mathrm{~cm}$ long single crystals.

At RPI, we are using the Submerged Heater Method (SHM) to grow GaSb and $\mathrm{Ga}_{\mathrm{I}-\mathrm{x}} \mathrm{In}_{\mathrm{x}} \mathrm{Sb}$ by directional solidification Ostrogorsky et al. $(1990,1994)$. We expect the SHM to yield large boules, having low dislocation density and high compositional homogeneity. The SHM is shown schematically in Fig. 8 . The crucible and the submerged heater are made out of silica or PBN. A multi-zone tubular furnace controls the axial radial heat flow. The melt is solidified by lowering the crucible while the submerged heater and multi-zone furnace remain at a fixed position. While the crucible is lowered, the large top melt provides a liquid feed of a constant composition of $\mathrm{C}_{0}$ to the small enclosed melt. The downward flow in the gap (between the crucible wall and the submerged heater) prevents back diffusion. Because of the separation between the feed material and the melt at the interface, the Submerged Heater Method may be ideal for growth of ternary III-V alloys. 


\section{TPV Cell Fabrication Considerations}

TPV cell fabrication considerations are similar to those in high-concentration solar cells with a few exceptions. First, the spectral control requirements that are necessary for TPV can be integrated within the cell to avoid module mounting complexity at the expense of increased cell complexity and cost. In the short term, however, hybrid integration of the spectral control filter and the cell will be flexible and cost effective. Second, fabrication issues for low band gap cells have different junction constraints compared to wider band gap solar cells. In particular, dark current leakage, both bulk junction and edge currents, is more significant and places a lower bound on the band gap that is feasible. Finally, low ohmic contact specific resistance is needed to reduce parasitic power loss in the TPV cell and at the same time it should minimize the free carrier absorption of below band gap energy radiation.

The top-contact, patterned conducting grid is a similar constraint as with high concentration ratio solar cells. In order to avoid excessive series resistance and to avoid significant blockage of the IR photon flux, a thick metal pattern is needed. We have found that a two-level resist exposure process leads to reliable lift-off patterning with evaporated metallization. Both silver, more popular with high concentration ratio solar cells, and copper, a metallization technology under active development for future integrated circuits and widely used at the module level, have been successfully used for the ohmic contact. The ohmic contact metallurgy used for many compound semiconductors contains silver as a top layer, so that continued evaporation, sputtering, or electroplating of silver is usually employed.

Forming the active $\mathrm{p}-\mathrm{n}$ junction is an important part of the TPV cell fabrication. With epitaxially grown base layers using MOVPE, the junction is readily done during the growth process with graded doping and alloy composition possible to optimize performance. If bulk materials like GaSb or GalnSb wafers are used, diffused junction needs to be considered. A lower cost fabrication process, will result with diffused junctions into appropriately doped substrates such as GaSb or even GaInSb. However, diffused junctions need further research with these low band gap materials. Ion implantation for forming junctions appears more difficult than diffused junctions with these materials.

It should be noted that spectral control needs can complicate normal device processing, particularly with back-surface reflector (BSR) devices. Here, the free carrier absorption of belowband gap radiation has to be minimized. However, the potential of surface texturing to maximize photon coupling into the device and polycrystalline cells to achieve lower cost as done with photovoltaic needs to be considered. The tradeoff of TPV cell cost, efficiency, and power density is not straightforward; and further research and development is needed before first-order tradeoffs with any validity can be established.

\section{Conclusions}

Significant development has to be carried out in order to ascertain an ideal material system for TPV generation of electricity. Research in TPV cells and in emitters (both black body and selective) has to go together since overall system efficiency is interdependent. We have reviewed several cell related issues and the materials used for TPV cells in this paper. 


\section{Acknowledgement}

The authors acknowledge the contributions of many Rensselaer colleagues in the TPV program, particularly Dr. Hassan Ehsani. We gratefully acknowledge the support of the Lockheed Martin Corporation in our TPV research and educational program.

\section{References}

[1] Aigrain, P., 1960-61, "Thermophotovoltaic Converter", unpublished lectures given at the Department of Electrical Engineering, M.I.T., Cambridge, MA.

[2] White, D. C., Wedlock, B. D., and Blair, J., 1961, "Recent advances in thermal energy conversion", Proceedings, 15th Power Sources Conference, 125-132.

[3] Wedlock, B. D., 1963, "Thermophotovoltaic conversion", Proceedings of the IEEE, Vol. 51, pp. 694-698.

[4] Choi, H. K., Turner, G. W., and Eglash, S. J., 1994, "High power GaInAsSb-AlGaAsSb multiple quantum well diode lasers emitting at $1.9 \mu \mathrm{m} "$, IEEE Photonics Technology Letters, Vol. 6, pp. 7-9.

[5] Milnes, A. G., Polyakov, A. Y., 1993, "Gallium antimonide device related properties", Solid State Electronics, Vol. 36, pp. 803-818.

[6] Iyer S., Hegde, S., Abul-Fadi, A., Bajaj, K. K., and Mitchel, W., 1993, "Growth and photoluminescence of GaSb and GaInAsSb grown on GaSb substrates by LPE", Physical Review Vol. B47, pp. 1329-1339.

[7] Ehsani, H., Bhat., I., Hitchcock, C., Borrego, J., and Gutmann, R., 1996, "Characteristics of $\mathrm{GaSb}$ and GaInSb layers grown by metalorganic vapor phase epitaxy", Proceedings, Second NREL Conference on the Thermophotovoltaic Generation of Electricity, Benner J. P. et al., ed., American Institute of Physics, Woodbury, NY, Vol.358, pp. 423-433.

[8] Wojtczuk, S., Gagnon, E., Geoffroy, L., and Parodos, T., 1995, "InGaAs thermophotovoltaic cell performance versus band gap", Proceedings, First NREL Conference on the Thermophotovoltaic Generation of Electricity, Coutts T. J. and Benner J. P. ed., American Institute of Physics, Woodbury, NY, Vol. 321, pp. 177-187.

[9] Sharps, P. R., Timmons, M. L., Venkat, R., Hills, J. S., Quinn, B. O., Hutchby, J. A., Iles, P. A., and Chu, C. L., 1995, "Thermal photovoltaic cells", Proceedings, First NREL Conference on the Thermophotovoltaic Generation of Electricity, Coutts T. J. and Benner J. P. ed., American Institute of Physics, Woodbury, NY, Vol. 321, pp. 194-201.

[10] Hurle, D. T. J. and Cocayne, B., "Czochralski Growth", 1994, "Convection in melt growth", Chapter 3 in the Handbook of Crystal Growth, Vol. 2a, D.T.J. Hurle, Editor, North-Holland/Elsevier, pp. 99-213.

[11] Monberg, E., 1994, "Bridgman and related techniques", Chapter 2 in the Handbook of Crystal Growth, Vol. 2a, D.T.J. Hurle, Editor, North-Holland/Elsevier, pp. 51-99.

[12] Sunder, W. A., Barns, R. L., Kometani, T. Y., Parsey, Jr., J. M. and Laudise, R. A., 1986, "Czochralski growth and characterization of GaSb" J. Crystal Growth 78, pp. 9-18.

[13] Bonner, W. A., Nahory, R. E., Gilchrist, H. L., and Berry, E., 1990, "Semi-insulating single crystal $\mathrm{Ga}_{1-\mathrm{x}} \mathrm{In}_{\mathrm{x}} \mathrm{As}$ : LEC growth and characterization", Proceedings, 6 th Conference on Semi-insulating III-V Materials, Toronto, Canada, pp. 198-204.

[14] Kusunoki, T., Nakajima, K., and Kuramata, K., 1993, "Constant temperature LEC growth of uniform composition InGaAs bulk crystals through continuous supply of GaAs", Inst. Phys. Conf. Ser. No 129: Chapter 2, IOP Publishing Ltd. 
15] Garandet, J. P., Duffar, T., and Favier, J. J., 1990, "Vertical gradient freeze growth of ternary GaSb-lnSb crystals", J. Crystal Growth 106, pp. 426-436.

[16] Tanaka, A., Watanabe, A., Kimura, M., and Sukegawa, T., 1994, "The solute-feeding Czochralski method for homogeneous GaInSb bulk alloy pulling", J. Crystal Growth 135, pp. 269-272.

[17] Ostrogorsky, A. G., Mosel, F., and Schmidt, M. T., 1990, "Diffusion controlled distribution of solute in $\mathrm{Sn}-1 \% \mathrm{Bi}$ specimens solidified by the submerged heater method" Journal of Crystal Growth 110, pp. 950-954.

[18] Ostrogorsky, A. G., and Müller, G., 1994, "Normal and zone solidification using the submerged heater method", J. Crystal Growth 137, pp. 64-71. 


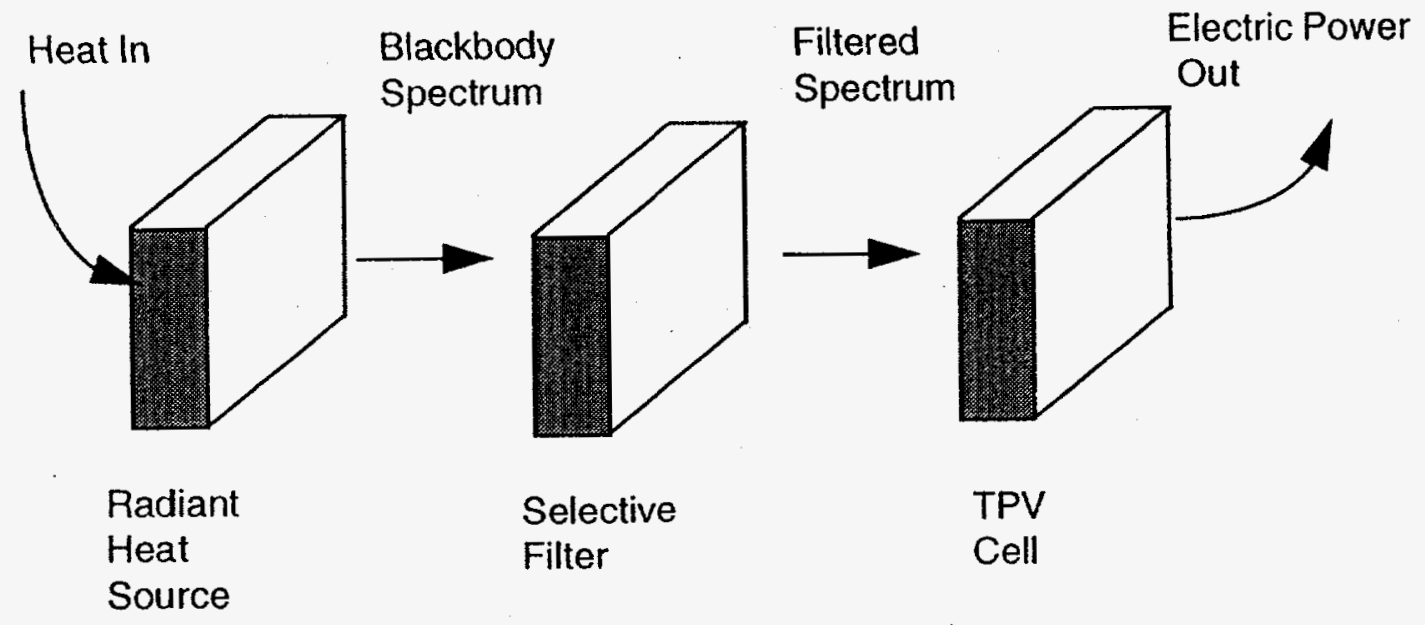

Figure 1 Schematic diagram of TPV energy conversion system 


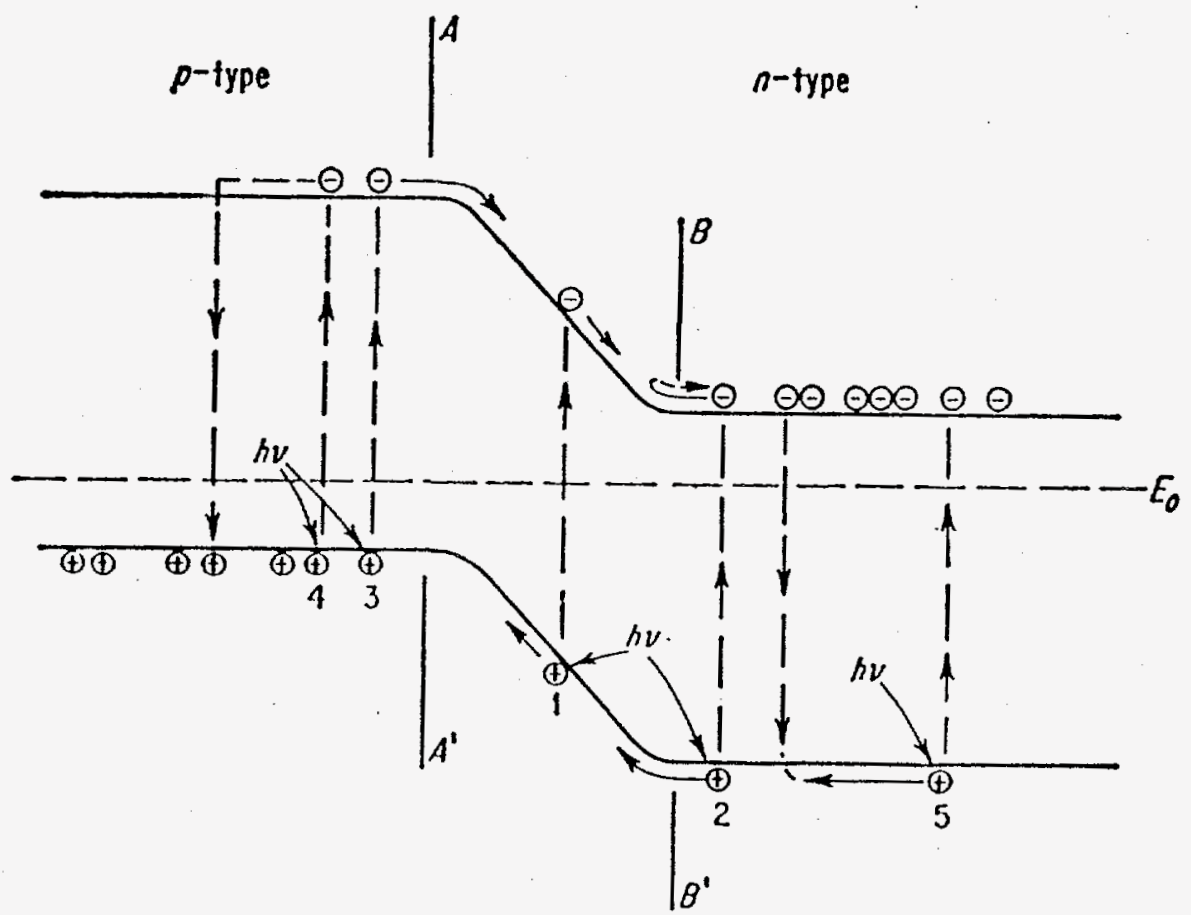

Figure 2 Generation of photovoltaic current in a PN junction 


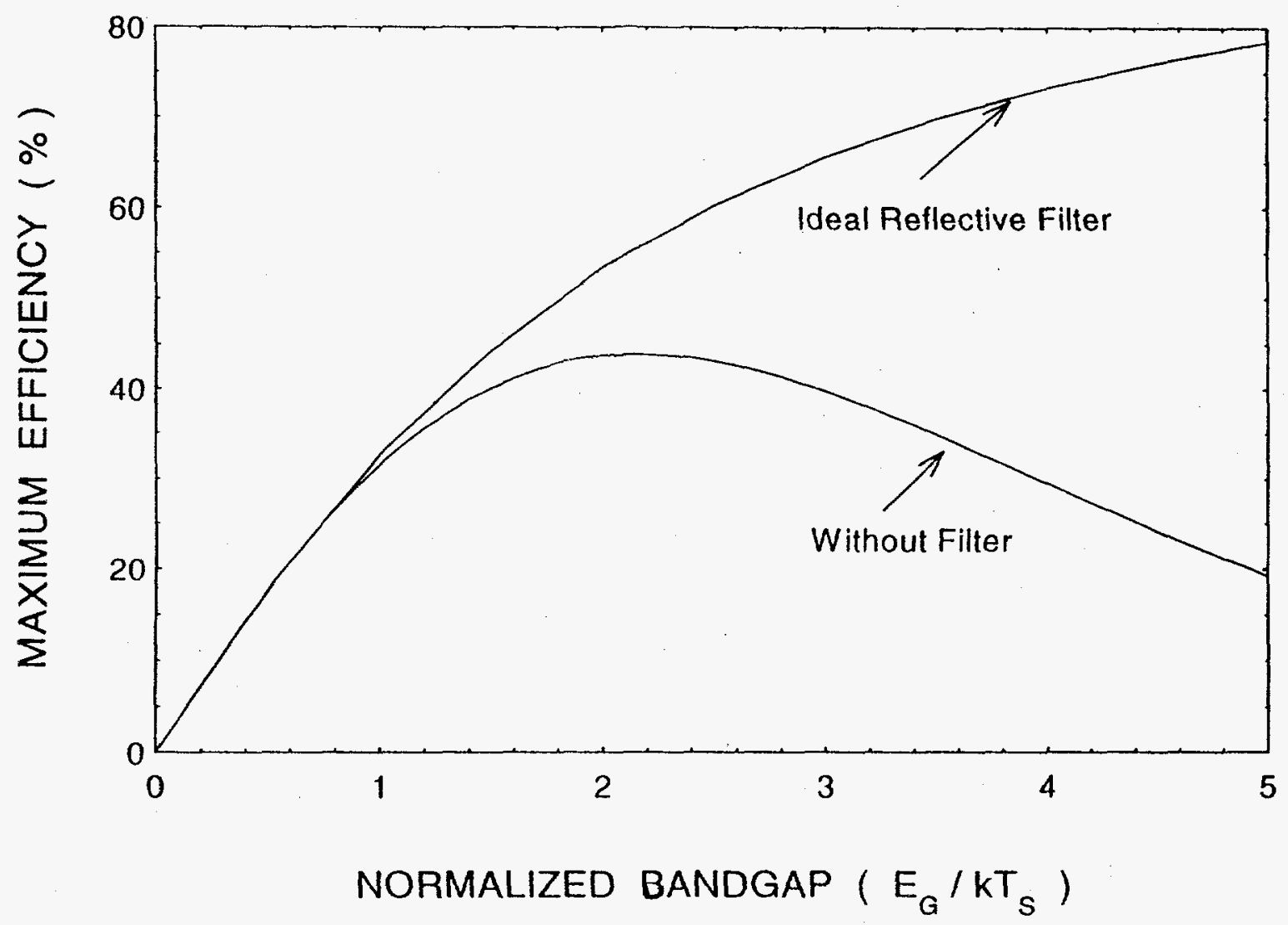

Figure 3 Efficiency of a TPV cell with and without filters 


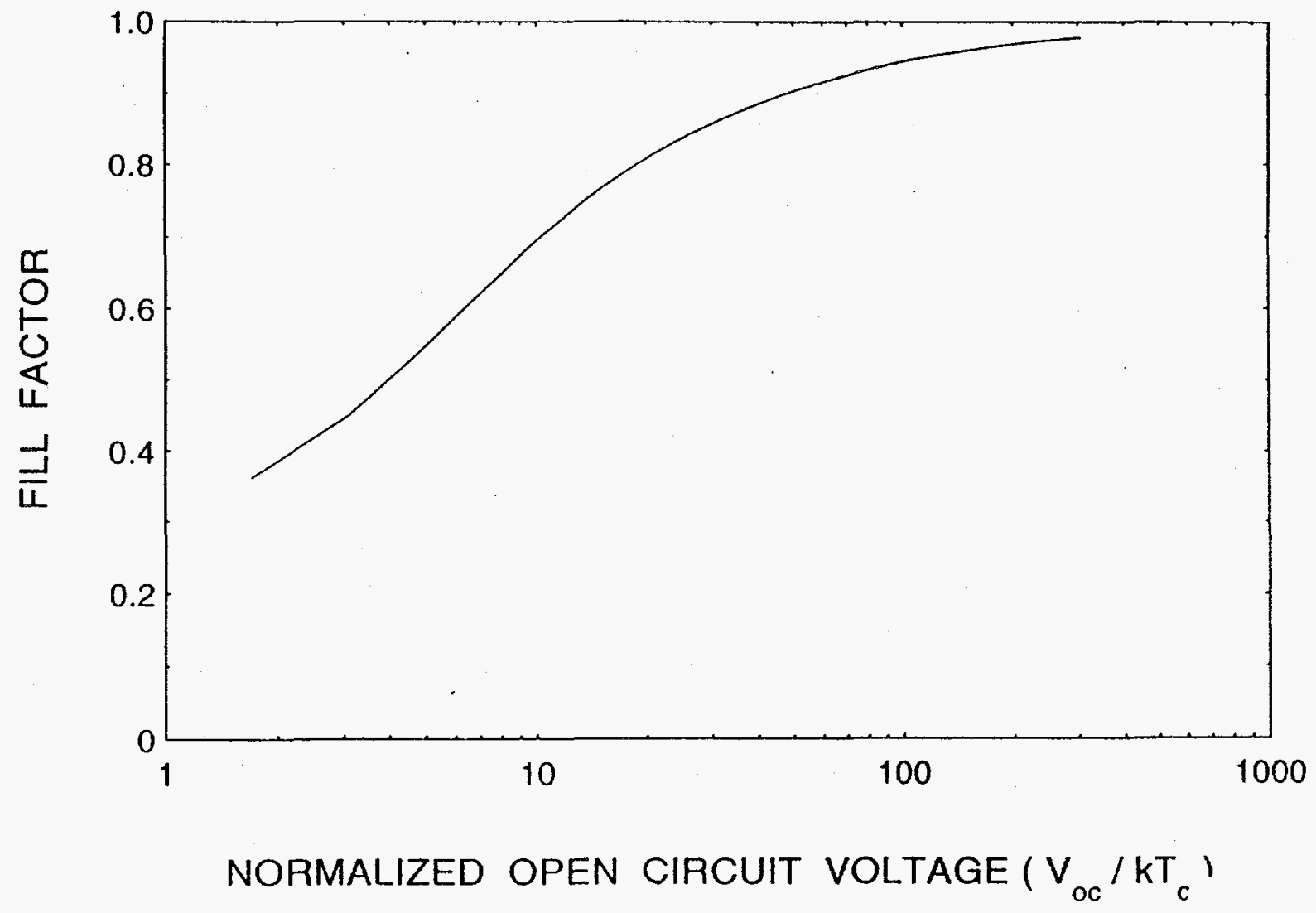

Figure 4 Fill Factor as a function of open circuit voltage 


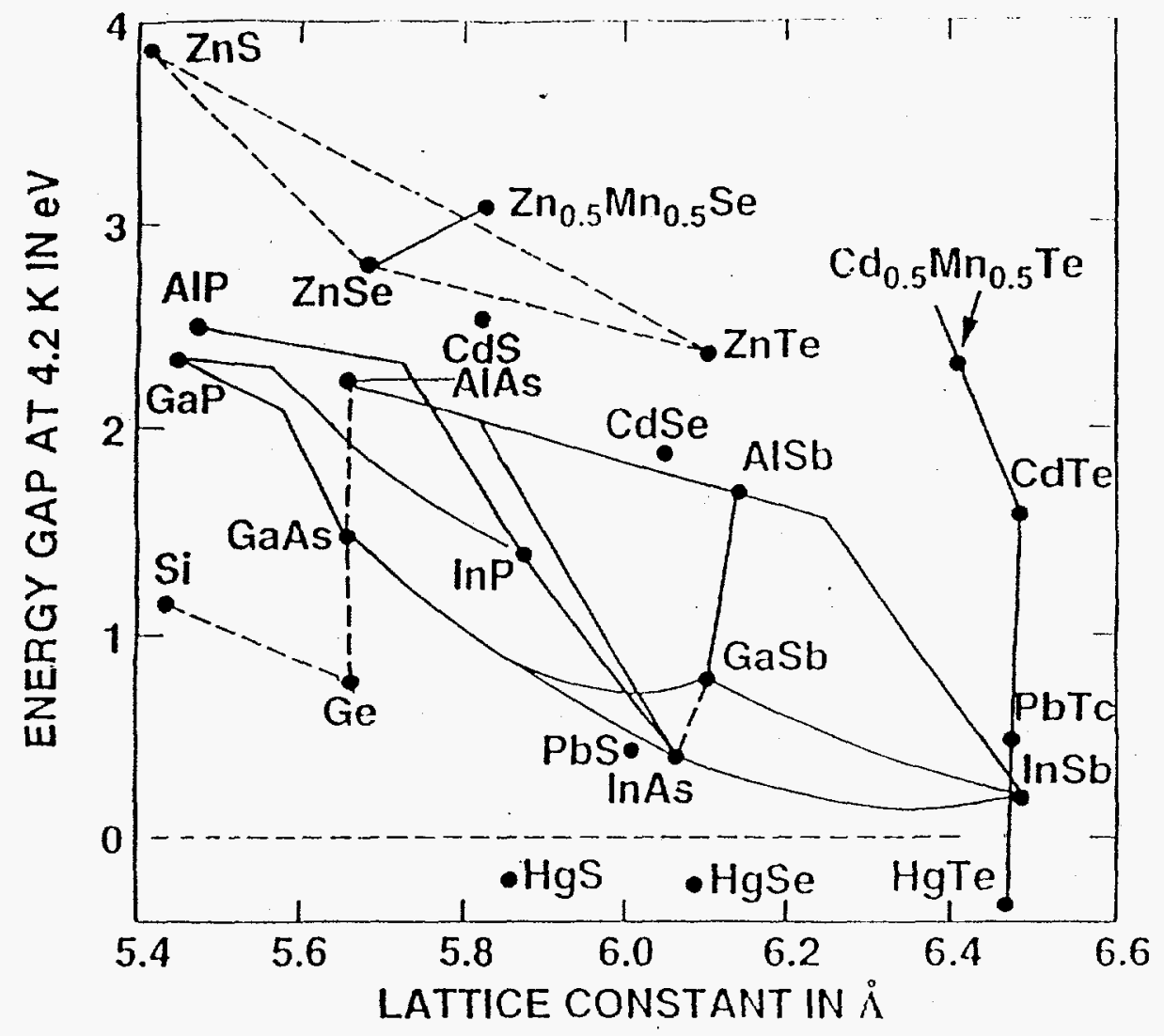

Figure 5 Bandgap and lattice constant data on some III-V and II-VI compound semiconductors 


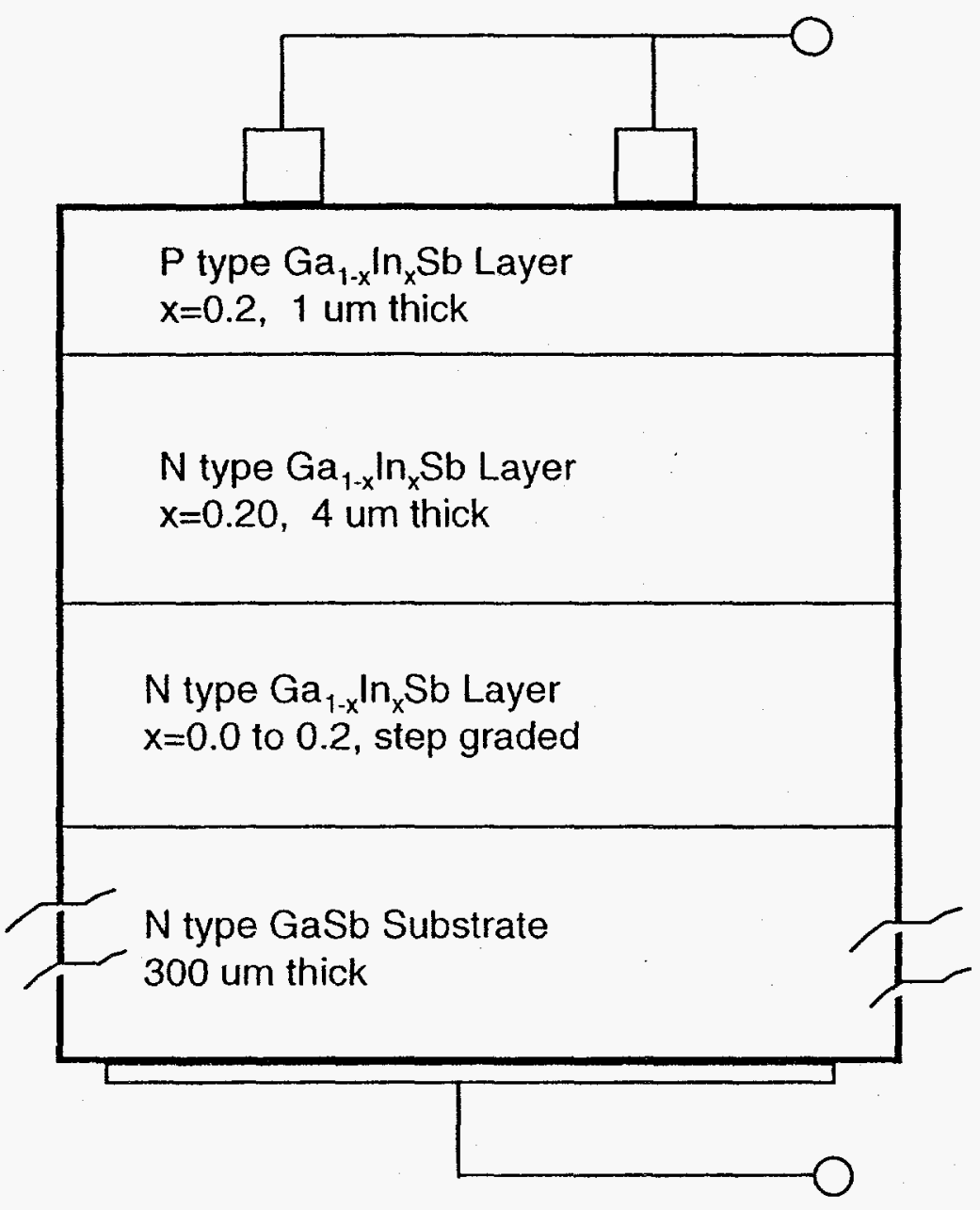

Figure 6 Schematic of a GaInSb TPV structure grown on $\mathrm{GaSb}$ substrate 


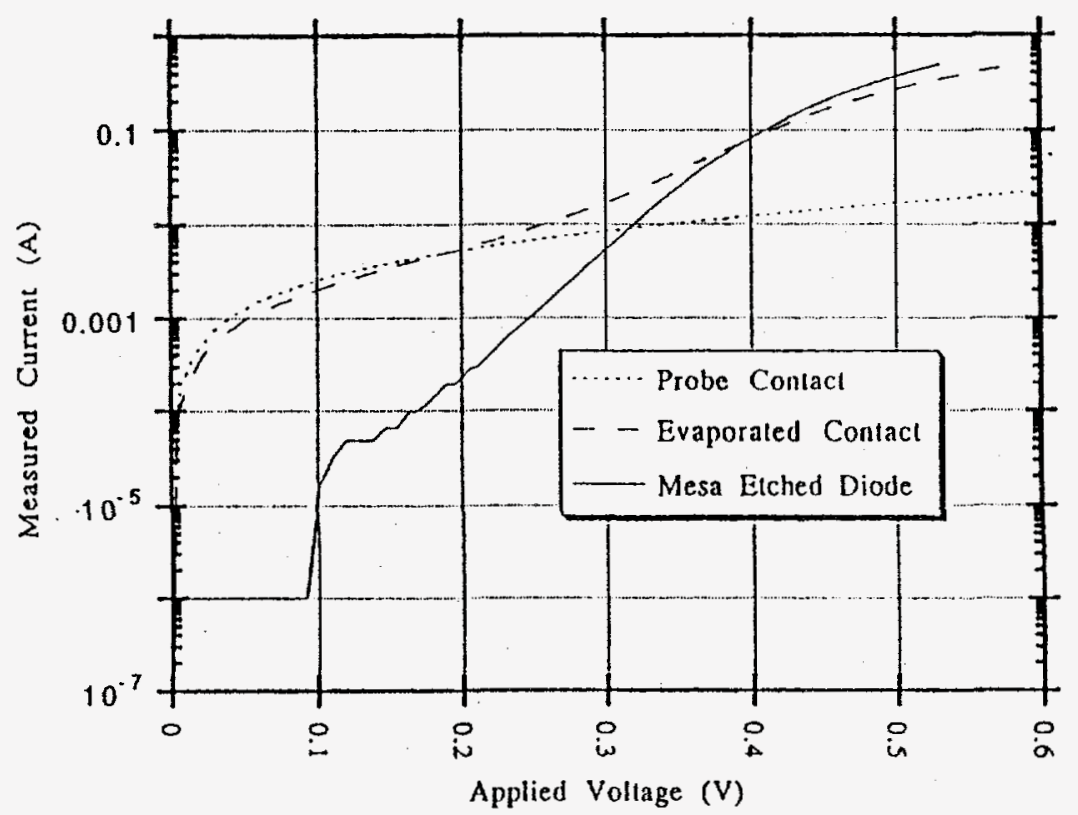

Figure 7 I-V characteristics of a small area PN junction diode fabricated in GaInSb 
